\title{
Breast at back passage-neonatal central perineal accessory breast at the site of an imperforate anus
}

\author{
Ramnik V Patel, ${ }^{1,2}$ Nordeen Bouhadiba, ${ }^{3}$ Rang Shawis, ${ }^{4}$ Jenny Walker ${ }^{4}$
}

${ }^{1}$ Department of Paediatric Urology, University College London Hospitals NHS Foundation Trust, London, UK ${ }^{2}$ Department of Paediatric Urology, Great Ormond Street Children Hospital NHS Trust, London, UK

${ }^{3}$ Department of Paediatric Surgery, Evelina Children Hospital, London, UK ${ }^{4}$ Department of Paediatric Surgery, SCH, Sheffield, UK

\section{Correspondence to}

Ramnik V Patel

ramnik@doctors.org.uk

\section{(a) CrossMark}

To cite: Patel RV, Bouhadiba N, Shawis R, et al. BMJ Case Rep Published online: [please include Day Month Year] doi:10.1136/bcr-2013203009

\section{DESCRIPTION}

A term baby girl weighing $3400 \mathrm{~g}$ was born by normal vaginal delivery following normal prenatal scans and an uneventful pregnancy. Baby did not pass meconium for $24 \mathrm{~h}$. She was found to have an imperforate anus and at the site of the presumed anus, there was a soft lump instead without any secondary changes. Nasogastric tube size 10 could be passed easily into the stomach and there was no perineal fistulous opening or any tracts with meconium and a high variety of anorectal malformation with a perineal hamartoma at the site of an imperforate anus was diagnosed. There were no other associated anomalies. Neonatal left descending colostomy followed by posterior sagittal anorectoplasty after excision of the hamartomatous lesion was carried out uneventfully. The colostomy was closed after 6 weeks. She is asymptomatic and thriving well at 5 -years of follow-up. The histopathological examination of the excised 'hamartoma' at the site of an imperforate anus showed structure of matured mammary gland (figure 1A). To the best of our knowledge, this is the first case of accessory breast tissue arising at the anus, an imperforate anus simulating hamartoma. There are two earlier reports of it presenting as anal polyp and mass at the anal verge. ${ }^{12}$ Mammary or milk line appears at 6 weeks of embryonic life from axillae and converge down in the perineum ${ }^{3}$ and condenses in the form of a mammary ridge at 2-3 months gestation from which supernumerary nipple or breast develops (figure 1B).

\section{Learning points}

- Anal accessory breast at the site of an imperforate anus has not been reported and is the first documented case.

- Accessory breast can be found anywhere along the milk line or mammary ridge or may be found elsewhere due to aberrations in the development and high index of suspicion together with early excision would clinch the diagnosis.

- The treatment of choice for accessory breast is excision because it is amenable to all hormonal, congenital and acquired lesions of the normal breast including malignant lesions.

Contributors All the authors have made substantial contributions to the conception and design of this paper, search of literature, the acquisition, analysis and interpretation of the data, to drafting the article or revising it critically for important intellectual content, and to the final approval of the version to be published.

Competing interests None.
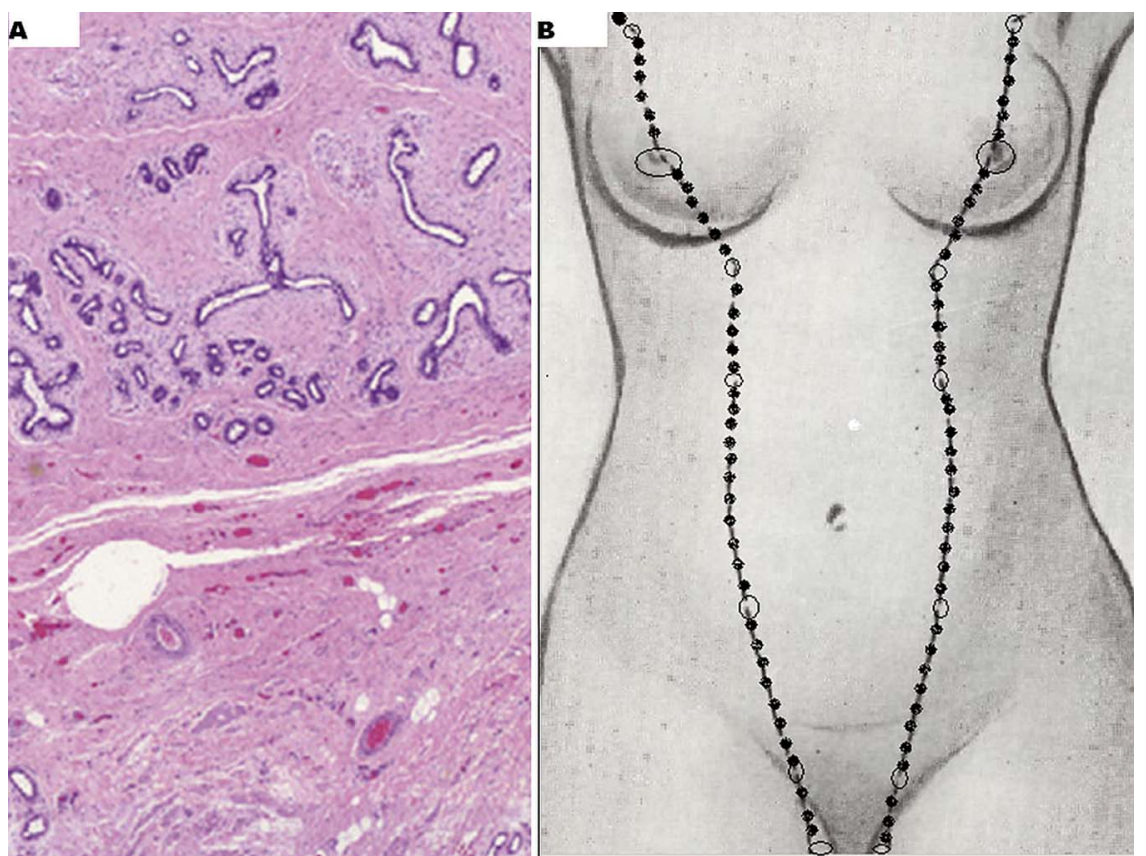

Figure 1 (A) Microphotograph showing mature breast glands and stroma ( $\mathrm{E} \& \times 40)$. (B) Schematic presentation of embryonic mammary line oval empty circles is the possible sites of accessory nipples or breast. 
Patient consent Obtained.

Provenance and peer review Not commissioned; externally peer reviewed.

\section{REFERENCES}

1 Fitzmaurice GJ, Hurreiz $\mathrm{H}, \mathrm{McGalie} C \mathrm{C}$, et al. Ectopic breast tissue at the anal verge —an unusual finding. Int/ J Colorectal Dis 2010;25:1031-2.

Copyright 2014 BMJ Publishing Group. All rights reserved. For permission to reuse any of this content visit http://group.bmj.com/group/rights-licensing/permissions.

BMJ Case Report Fellows may re-use this article for personal use and teaching without any further permission.

Become a Fellow of BMJ Case Reports today and you can:

- Submit as many cases as you like

- Enjoy fast sympathetic peer review and rapid publication of accepted articles

- Access all the published articles

- Re-use any of the published material for personal use and teaching without further permission

For information on Institutional Fellowships contact consortiasales@bmjgroup.com

Visit casereports.bmj.com for more articles like this and to become a Fellow
2 Chan NG, Penswick JL, Labelle E, et al. Ectopic breast tissue presenting as an anal polyp. Can J Surg 2007;50:E23-4.

3 Dixon JM, Mansel RE. ABC of breast diseases: congenital problems and aberrations of normal breast development and involution. BMJ 1994;309:797-800. 